\title{
The oil \& protein crop supply chain in South America: introduction
}

\author{
Jean-François Mittaine* \\ Fish Oil \& Meal World, Fishmeal Experts Office, 2 rue des Bois, 92410 Ville d'Avray, France
}

Received 24 January 2018 - Accepted 25 January 2018

The South American sub-continent is characterized by a great diversity of geographical and climatic configurations. This diversity has a clear impact on the oleo-protein complex, which is itself characterized by immense biodiversity, part of which remains to be explored in this vast territory which is the Amazonian forest.

Stretching from the tropical zones of the northern hemisphere to the regions close to Antarctica, that is to say practically from parallel $10^{\circ} \mathrm{N}$ to parallel $55^{\circ} \mathrm{S}$, South America offers a wide range of climates allowing the cultivation of plants from both temperate and tropical climates. Temperate crops include sunflower, grown mostly in Argentina, while rapeseed is grown in Chile, Paraguay and Argentina. On the other hand, palm trees, a typical tropical production, are planted in Colombia, Ecuador and Brazil.

In its oriental part, very large relatively flat spaces are fairly accessible with variable but generally low elevations, while, in its western part, the Andean range is very high and inaccessible, oriented towards the Pacific Ocean.

The South American sub-continent, covering 17.8 million $\mathrm{km}^{2}$, represents almost $12 \%$ of the emerged land areas. But its 435 million inhabitants represent only $6 \%$ of the world's population and less than half the population of the entire American continent. It is therefore a relatively sparsely populated area all the more that major megacities dot the continent, mostly close to the oceans, such as Sao Paulo, Rio de Janeiro, Lima, Buenos Aires and Santiago de Chile, hosting several millions inhabitants. This is the reason why, in the past four decades, there has been a huge development of arable land, frequently at the expense of the wild forest.

But these large urban conurbations are also important centers of economic activity generating demand for food, biodiesel and all non-food usage which may come from the rational use of oilseeds by-products. This economic growth enabled many of these countries to develop a significant economic role at the global level, such as Brazil, which is part of the fast growing "BRIC" group of countries.

Oilseed production is currently totally dominated by soybeans, a relatively new crop in this part of the world, but a

\footnotetext{
*Correspondence: jfmittaine@gmail.com
}

fast growing one. With a crop around 185 million tons in 2016/ 2017, South American soybeans production now represents more than half world production $(53 \%)$, of which $60 \%$ is grown in Brazil, 30\% in Argentina and 10\% in Paraguay with some in Uruguay and Bolivia (Oil World Annual, 2017). Starting from practically nothing about half a century ago, soybean production continues to grow thanks to huge developments and innovation in agronomy. Even more recently, soybean production increased nearly twofold in the past seven years with Brazilian crop rising from 57 million tons in 2008/2009 to about 113 million tons during the same period (Oil World Annual, 2017). All other crops are much smaller in size except sunflower seed crop, the second largest oilseeds crop at 3.6 million tons in the 2016/2017 crop year, practically all located in Argentina(Oil World Annual, 2017).

Although South American oilseeds crops represent nearly $35 \%$ of world oilseeds crops, the continent holds a much smaller role in the production of oils and meals. Only $12 \%$ of world fats and oils and $25 \%$ of world meals are produced in South America (Oil World Annual, 2017). Actually, in spite of the presence of a large crushing industry in both Argentina and Brazil, the expansion of the soybean crop has essentially benefited to the export market, all the more that, during that time China has become the largest buyer of soybeans.

The following pages logically include two reports discussing the soybean context in South America, how its rapid growth in Brazil was made possible thanks to huge changes in agronomic practices, innovation and entrepreneurial dynamism enabling this large production to serve the world markets not only as grains but also as vegetable oil, biodiesel and proteins (Cattelan and Dall'Agnol, 2018; Guibert, 2018). Two other reports discuss the potential for sunflower seed production in both Brazil (de Castro and Leite, 2018) and Argentina (Castaño, 2017) to become key players on the world market for this high yielding vegetable oil crop at a time of rising world vegetable oil requirements. But the three following reports also discuss the high potential that other crops will likely become significant factors on both the food and no-food markets (Gomes Pereira et al., 2017; Teles dos Santos et al., 2018), particularly how palm oil is also proving to be potentially another asset for South American countries located 
in tropical regions (Colombo et al., 2017). Finally, the last report discusses the development of fats and oil consumption in Argentina (Sebillotte, 2018), as an example of key trends that will potentially modify the nutritional situation of its population and how public policies are important to protect the populations from excessive trans-fatty acid intake.

\section{References}

Castaño FD. 2017. The sunflower crop in Argentina: past, present and potential future. OCL 25: D105.

Castro C, Leite RMVBC. 2018. Main aspects of sunflower production in Brazil. OCL 25: D104.

Cattelan AJ, Dall'Agnol A. 2018. The rapid soybean growth in Brazil. OCL 25: D102.
Colombo CA, Chorfi Berton LH, Diaz BG, Ferrari RA. 2017. Macauba: a promising tropical palm for the production ofvegetable oil. OCL 25: D108.

Guibert M. 2018. Le pôle sojicole sud-américain. OCL 25: D103.

Oil World Annual. 2017. ISTA Mielke GmBH, 25 Langenberg, 21077 Hamburg, Germany.

Pereira FSG, de Sobral AD, da Silva AMRB, da Rocha MAG. 2017. Moringa oleifera: a promising agricultural crop and of social inclusion for Brazil and semi-arid regions for the production of energetic biomass (biodiesel and briquettes). OCL 25: D106.

Santos MTD, Morgavi P, Le Roux GAC. 2018. Exploring Amazonian fats and oils blends by computational predictions of solid fat content. OCL 25: D107.

Sebillotte C. 2018. L'Argentine dans le contexte latino-américain : consommations alimentaires, santé et politiques nutritionnelles. OCL 25: D109.

Cite this article as: Mittaine J-F. 2018. The oil \& protein crop supply chain in South America: introduction. OCL 25(1): D101. 